\title{
Service Quality and Customer Satisfaction: The Case of Star Cruise Libra, Penang
}

\author{
Albattat Ahmad" \\ Post Graduate Centre, Management and Science University, University Drive, Off Persiaran Olahraga, Section 13, 40100, Selangor, Malaysia \\ Al-Laymoun Mohammad \\ Ammon Applied University College, 950271 Amman 11195, Jordan \\ Alsardia Khaled \\ Ammon Applied University College, 950271 Amman 11195, Jordan \\ Mohd Shukri Ab Yajid \\ Post Graduate Centre, Management and Science University, University Drive, Off Persiaran Olahraga, Section 13, 40100, Selangor, Malaysia \\ Abdol Ali Khatibi \\ Post Graduate Centre, Management and Science University, University Drive, Off Persiaran Olahraga, Section 13, 40100, Selangor, Malaysia
}

\begin{abstract}
Quality of service is a major competitive advantage within the tourism industry and cruise liners are no exception. In recent years, the Asian-Pacific company Star Cruises has striven to strengthen and retain the loyalty of its customer base in an increasingly challenging market. This study aims to look at the interface between Star Cruises' service quality dimensions and customer satisfaction level by analyzing data on one of its ships, the Super Star Libra, with its homeport in Penang, Malaysia. An adapted version of the SERVQUAL model was used by the researchers to evaluate the quality of service and customer satisfaction aboard the Libra, as was a questionnaire, whose instruments were developed from past studies. 102 questionnaires were given out to and collected from passengers who had ridden aboard the Super Star Libra. Results indicated that service quality dimensions such as tangibility, responsiveness, reliability, assurance, and empathy had a significant bearing on customer satisfaction. The latter also helped determine which cruise customers would prefer to spend their vacations on in the future. The outcome of this research provides useful guidelines for cruises that intend to capitalize on the quality of their service to both maintain the satisfaction of their existing customers and attract more potential customers going forward.
\end{abstract}

Keywords: Service quality; Customer satisfaction; Star cruise; Penang; Tourism product.

\section{(9) (1) CC BY: Creative Commons Attribution License 4.0}

\section{Introduction}

Tourism is the world's largest income earner. It is a popular global leisure activity and the arrival of guests from abroad helps bolster a nation's economy in many ways. Tourist spending helps promote investment and growth, which is why many governments require international visitors to bring a specific amount of currency with them to be used in-country solely for the duration of their visit. This policy enables the host country to utilize foreign capital to stimulate its economy, both within the tourism sector and otherwise (Martinez-Garcia and Raya, 2008).

Cruises have gone from a once prohibitively expensive mode of transoceanic transportation accessible only to society's elite to a now multi-million-dollar industry offering a wide variety of very affordable vacation options. A relatively small number of cruise line businesses compete for global market shares by investing heavily in the building of state-of-the-art hotel ships that boast luxurious and comfortable living spaces and sport cutting-edge naval construction designs all while adhering to the highest standards of safety (Dowling, 2006). Increasingly, some companies specialize in catering to niche customers looking to travel to more remote, exotic, and "pristine" destinations on smaller ships, sailing vessels, and yachts that carry just a few hundred passengers or less (Kjell, 2013).

Zeithaml et al. (1996), initially came up with ten dimensions to service quality, which they later combined into five because of strong intra-correlation determined upon further research: Reliability, Responsiveness, Assurance, Empathy and Tangibles. These formed the basis for a testing tool for service quality called SERVQUAL, applicable in a range of domains from financial institutions to medical centers to libraries to hotels (Parasuraman et al., 1994). Although SERVQUAL is widely agreed upon as a reliable research instrument, some controversy does exist surrounding its dimensional schema and breadth of applicability. Further, Rust and Oliver identified three distinct components to perceptions of service quality comprising the product (technical quality), delivery (functional quality), and environment (Parasuraman et al., 1988).

Tourism can be defined as short-term (less than a year) travel to and spending of time in destinations outside of the usual environments where customers live and work. The term "usual environments" excludes travel undertaken 
within one's area of permanent residence as well as frequent trips made on a routine basis, such as a drive from home to work (Shen et al., 2013).

The complexity of the tourist "product" makes conceptualizing tourist satisfaction challenging (Smith, 1994). For example, increased global competition among vacation hotspots and, more precisely, DMOs (Destination Management Organizations) means determining the current and future success of a destination requires strategic analysis (Pizam and Ellis, 1999). The purpose of this study is to pinpoint those factors that make cruise liners and their destinations more competitive (Kozak and Rimmington, 1999) and contribute to customer satisfaction or dissatisfaction.

Today's cruise tourist is often looking for a one-of-a-kind experience and no longer feels content with a run-ofthe-mill package of amenities and facilities (Pizam and Ellis, 1999). Cultivating customer satisfaction, which of course influences the likelihood of future purchases, thus requires meeting this increasing demand for uniqueness and novelty (Mittal and Kamakura, 2001). Positive word of mouth among past and potential customers is one of the best marketing tools in this regard and plays an especially important role in Middle Eastern and other cultures that place a premium on frequent socializing (Pizam and Ellis, 1999).

Customer satisfaction has often been described as the perceived harmony between expectation and performance and Parasuraman et al. (1991) mentioned that one's level of satisfaction is determined after the experience of a product or service. On the other hand, (Liljander and Strandvik, 1993) maintain that experience is not a prerequisite for assessing service quality, which can be effectively evaluated based on knowledge about the service provider since satisfaction is subjectively perceived by the customer (Cadotte and Turgeon, 1988). Other research suggests a two-way relationship between satisfaction and service wherein the degree to which a customer is satisfied will over time influence the quality of service delivered (Parasuraman et al., 1988; Pizam and Ellis, 1999; Sureshchandar et al., 2002).

Quality within the framework of service industries includes static as well as dynamic dimensions (Bloemer et al., 1998). Static dimensions refer to customer expectations that become fixed and established aspects of service such as the offering of in-flight drinks and snacks. Dynamic dimensions are more spontaneous and unscripted and give staff the opportunity to make the experience of their customers more memorable, for example, by helping them access in-flight movies or providing them with extra pillows and blankets as requested. Dynamism in service is harder to achieve yet reaps big rewards in achieving customer satisfaction (Malhotra and Mukherjee, 2004).

Regardless of how service quality is defined, a tourism industry player must cater to customer needs first and foremost as well as achieve its quality goals consistently. More new and repeat tourists lead to more revenue for companies, which boosts performance-based pay to staff thus enhancing service quality in addition to facilitating investment in facility upgrades that help to exceed customer expectations (Albattat et al., 2019; Eraqi, 2006). While both service quality and customer satisfaction have been researched broadly within hospitality and tourism studies, little remains known about satisfaction in the specific context of the all-inclusive holiday sector. The objective of this research is to shine a light on the intricate and inter-influencing relationship between service quality and customer satisfaction aboard Star Cruises’ SuperStar Libra.

\section{Literature Review}

\subsection{Service Quality}

Service quality has been the subject of considerable interest from both practitioners and academics in recent years, spurred on by the original work of Parasuraman et al. (1985). An important reason for this interest is a belief among practitioners that high quality translates to bottom-line performance outcomes. However, they tend to use the terms "service quality" and "customer satisfaction" interchangeably. Among academics, the satisfaction construct is recognized as being independent of service quality (Caruana, 2002).

Coming up with a definition for service quality is challenging, yet marketing theorists are generally in agreement about its subjective nature: quality is in the eye of the beholder (González et al., 2007). The most widely used definitions of service quality integrate customer expectations with ever-evolving company perceptions (Parasuraman et al., 1985; Storbacka et al., 1994). For example, Wilson et al. (2012) understood service quality as "a global judgement or attitude relating to the superiority of a service." In addition, the five SERVQUAL dimensions - reliability, responsiveness, assurance, tangibles, and empathy - refer to the way customers think about and compartmentalize service quality (Atilgan et al., 2003). Of these dimensions, reliability - the ability of a business to accurately deliver on its promises - has consistently been shown to represent the most essential determinant of service quality (Wilson et al., 2012). Responsiveness denotes the capacity and willingness to assist customers promptly and without delay. Assurance speaks to the level of dependability and trust exhibited by employees. Empathy is demonstrated in the personalized attention and care given to each customer. The final dimension, tangibles, refers to equipment, facilities, and staff (Atilgan et al., 2003).

\subsection{Service Quality in the Cruise Industry}

Cruises today are experiencing record demand and growth with customers able to easily choose from more travel and destination products than ever before at the click of a button. There are a number of reasons for the increasing popularity of this all-inclusive travel package. First, cruise vacations offer a wide selection of facilities and services at an affordable cost from water parks and planetariums to on-deck cinemas and high-tech billiard tables to multi-room villas and in-suite Jacuzzis. These can be enjoyed by a range of demographic groups - children and seniors, solo travelers, and groups alike. Passengers can also select a theme for their cruise, for example, 
"psychic healing," "sports," "singles," and even "all-nude” (Testa and Sullivan, 2002). With all this fantastic luxury and top-class entertainment, the voyage itself has become the attraction rather than its geographic destination. Gone are the days of catering to the rich alone - the modern cruise industry opens its doors to everyone and is now one of the fastest growing sectors of the travel industry. It is no wonder voice-of-customer programs have become one of the most effective marketing tools for cruise companies (Kwortnik and Han, 2011).

In comparison to other service-based industries, cruises arguably have a higher stake in customer satisfaction since the product is a veritable microcosm of the tourism and hospitality sector. From the moment they purchase their tickets to when they disembark from the ship, cruise passengers are continuously being exposed to the quality of service (Ostrowski et al., 1994). Even something as seemingly tangential as live entertainment on deck may lend cruise operators a value-added advantage since shows must be ever spectacular and unexpected to compete with performances aboard other ships (Testa and Sullivan, 2002). Cruise liner dining facilities are also well-known for the huge portion sizes they offer, yet often much more differentiating are food quality, variety, and presentation. For example, cruises can enhance the reputation of their restaurants through advertising featuring colorful images of dishes along with nutritional information for health-conscious passengers. Another major facet of customer perceptions is the in-cabin lodging experience, defined not simply by berth cleanliness, but more importantly stewards' hospitableness and attention to detail.

It is clear that the high visibility of quality (or lack thereof) on cruise liners affects customers' emotions and perceptions in immediate ways and has a direct impact on feelings of purchase value and future purchase behavior (Hsu and Lin, 2016; Kwortnik, 2008; Ostrowski et al., 1994). The rapid growth of the cruise industry - which has seen nine or more newly built vessels servicing the North American market added each year since 2001 to meet the demand of a 50\% first-time customer base - has led its leaders to shift their focus from new customer acquisition to customer retention (Kwortnik, 2006). It is thus essential for companies to identify and focus on those SERVQUAL dimensions that will enhance their differentiation and maximize the satisfaction of their customers, particularly their existing ones.

\subsection{Customer Satisfaction}

The satisfaction of a customer - an interaction between his or her pre-purchase expectations and post-purchase evaluations (Ndubisi and Nataraajan, 2018) is the primary factor in determining the quality of services delivered and is vital to the survival of a business (Vavra, 1997). Numerous studies have shown that attracting a new customer costs on average about five times as much money, resources, and time than retaining a current customer (Naumann and Giel, 1995). This can be attributed in part to the fact that services are often intangible, making it difficult for those on the receiving end to evaluate them prior to experiencing them (Smith et al., 2016). Unsurprisingly, offering high-quality service to increase satisfaction among consumers was identified in the 1990s as the foremost challenge facing businesses (Barsky and Labagh, 1992). The impact of a failure to measure and pay heed to those factors that influence satisfaction can be catastrophic for business considering that up to 60 percent of sales to new customers can be attributed to word-of-mouth referrals Poon and Lock-Teng Low (2005).

The academic literature on satisfaction measures it utilizing the transaction-specific approach and overall perspective. The former looks at satisfaction as a customer's emotional reaction to his or her most recent transaction, while the latter defines it as the accumulation of evaluations of past transactions (Bitner and Hubbert, 1994; Tsiotsou, 2006). Sashi (2012) mentioned that a consumer's overall satisfaction has a much better potential of promoting positive word of mouth and repeat purchases than individually based transaction-to-transaction satisfaction (Forgas-Coll et al., 2014).

Expectations have a major influence on satisfaction. Customers with high expectations will become disappointed when encountering a service that falls short and likely rate their experience as sub-par. For this reason, a luxury liner may receive a lower rating from customers than its mid-tier counterpart even though its facilities and services are viewed by the industry as objectively "superior" (Kwortnik, 2006). The challenge of customer retention can further be seen in the fact that some travelers, despite their overall satisfaction and positive word of mouth, may for a variety of reasons see a cruise as a one-time experience, which they are unlikely to have again. This explains why the established correlation between satisfaction and the three behavioral intention variables of "word of mouth," "recommendations," and "future patronage" are stronger for the former two than the latter (Heung and Lam, 2003; Mason et al., 2006).

The existing literature suggests that gaps between expectation and experiential perception are widest for criteria related to the SERVQUAL dimensions of empathy, responsiveness, and assurance. This speaks to the imperative to selectively hire and train onboard staff who have the qualities to provide cruise passengers with highly personalized service (Heung and Lam, 2003). In addition, segmentation analysis has shown major variations in how overall satisfaction was rated by first-time and repeat travelers as well as those traveling in different cabin classes respectively. Cruise operators thus need to have a strong customer relations department specially devoted to engaging with repeat customers as well as ensure a standard level of quality for facilities and amenities in quadsharing cabins (Kwortnik, 2006).

\subsection{Cruise Industry}

As one of the fastest-growing sectors within the tourism industry, cruise companies enjoyed an 8.4 percent annual growth rate from 1984 to 2002, spurred on by a boom in vessel construction in the 1990s. From 1970 to 2002, about 84 million people worldwide travelled on a cruise (Testa and Sullivan, 2002). During that same period, there were around 50 million deep-water cruise passengers from North America, which represents an estimated 82 
percent of the global cruise market. Demand has been steadily burgeoning in Asia, however, at a rate of nearly 7.6 percent annually since the 1980s and countries like Thailand, Vietnam, Cambodia, Malaysia, Indonesia, and Singapore are becoming increasingly popular destinations for international tourists (Ahmed et al., 2002; Coggins Jr, 2014).

\subsection{Star Cruises of the Genting Group}

Star Cruises is one of Asia's most successful cruise companies and the third biggest in the world. Founded as an associate of the Genting Group of Malaysia and incorporated in Bermuda in 1993, it started out with just two vessels. Today, Star Cruises boasts over 26,000 lower berths in a combined fleet of 20 ships comprising three different brands: Star, SuperStar, and MegaStar. The company has purchased a number of liners from other companies including the former Sun Viking from Royal Caribbean, the former Baltic ferries Athena and Kalypso, and the former Europa from Germany's Hapag-Lloyd (Testa and Sullivan, 2002). Destinations span all over the world from Asia-Pacific to Hawaii and the Caribbean to Alaska and Antarctica. Star Cruises, headquartered in Hong Kong, has offices in over 20 locations including Australia, China, Japan, Korea, Thailand, Malaysia, the Philippines, Germany, India, Norway, Switzerland, the United Kingdom and the United States (Testa and Sullivan, 2002).

Constructed in 1988, the SuperStar Libra - named after the cardinal seventh astrological Zodiac sign - features a gross tonnage of 42,275 and a capacity for 1,480 guests. The Libra originally belonged to Norwegian Cruise Line under the name Seaward and set off for its maiden voyage from Wartsila Shipyard in Finland. It became part of the Star Cruise family in 2005, ushering in a trend in the coming years of transferring the ownership of old ships from NCL to Star Cruises. For example, the Norwegian Dream joined the Star Cruise fleet in 2012 and was renamed SuperStar Gemini. After a nearly thirteen-year career on the seas, the SuperStar Libra's public cruise operations were discontinued last year and it now serves as a hotel ship for the MV Werften, a subsidiary of Genting Hong Kong (GentingBerhad, 2015).

\subsection{Theoretical Framework}

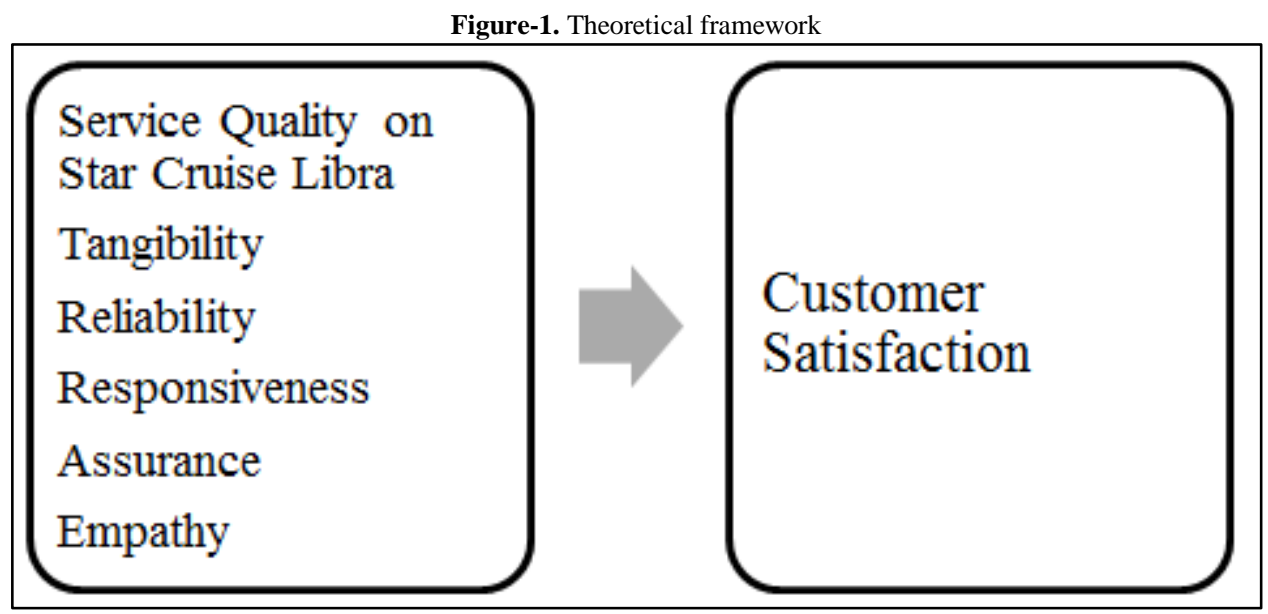

\subsubsection{Research Hypotheses}

H1: There is a positive relationship between service quality and customer satisfaction on Star Cruise Libra.

H01: Service quality reliability positively affects customer satisfaction on Star Cruise Libra

H02: Service quality responsiveness positively affects customer satisfaction on Star Cruise Libra.

H03: Service quality assurance positively affects customer satisfaction on Star Cruise Libra.

H04: Service quality empathy positively affects customer satisfaction on Star Cruise Libra

H05: Service quality tangible positively affects customer satisfaction on Star Cruise Libra.

\section{Research Methodology}

A quantitative approach was used for this study to find out the relationship between service quality and customer satisfaction on Star Cruise Libra, Penang. The data were collected using paper questionnaires and nonprobability sampling. The sample chosen for this study consisted of tourists who used Star Cruise Libra services. Data were analysed using SSPS. 


\section{Data Analysis and Findings}

Table-1. Demographic Analysis

\begin{tabular}{|c|c|c|c|}
\hline Item & & Freq. & Percentage \\
\hline \multirow[t]{2}{*}{ Gender } & Male & 54 & 52.9 \\
\hline & Female & 48 & 47.1 \\
\hline \multirow[t]{3}{*}{ Marital Status } & Single & 41 & 40.2 \\
\hline & Married & 55 & 53.9 \\
\hline & Other & 6 & 5.9 \\
\hline \multirow[t]{5}{*}{ Occupation } & Student & 19 & 18.6 \\
\hline & Own Business & 26 & 25.5 \\
\hline & Private & 27 & 26.5 \\
\hline & Government & 20 & 19.6 \\
\hline & Others & 10 & 9.8 \\
\hline \multirow[t]{5}{*}{ Age } & $18-20$ & 8 & 7.8 \\
\hline & $21-30$ & 31 & 30.4 \\
\hline & $31-40$ & 35 & 34.3 \\
\hline & $41-50$ & 19 & 18.6 \\
\hline & 50 and above & 9 & 8.8 \\
\hline \multirow{4}{*}{$\begin{array}{l}\text { Product Purchased on } \\
\text { Star Cruise }\end{array}$} & Café/lounge & 63 & 61.8 \\
\hline & Consumer goods & 1 & 1.0 \\
\hline & Skin care products & 10 & 9.8 \\
\hline & Other & 28 & 27.5 \\
\hline \multirow{3}{*}{$\begin{array}{lrr}\text { Star Cruise } & \text { Liner } \\
\text { Travelled With } & \end{array}$} & Superstar Libra & 98 & 96.1 \\
\hline & Superstar Aquarius & 3 & 2.9 \\
\hline & Superstar Gemini & 1 & 1.0 \\
\hline \multirow[t]{5}{*}{ Monthly Income } & Below $\$ 1000$ & 25 & 24.5 \\
\hline & $\$ 1001-\$ 1500$ & 15 & 14.7 \\
\hline & $\$ 1501-\$ 2000$ & 17 & 16.7 \\
\hline & $\$ 2001-\$ 2500$ & 15 & 14.7 \\
\hline & Above $\$ 2501$ & 30 & 29.4 \\
\hline \multirow{6}{*}{$\begin{array}{lcr}\text { General } & \text { Purpose } & \text { for } \\
\text { Travelling } & \text { with } & \text { Star } \\
\text { Cruise Libra } & & \end{array}$} & Vacation by the sea & 46 & 45.1 \\
\hline & $\begin{array}{l}\text { Quality time with } \\
\text { friends and family }\end{array}$ & 36 & 35.3 \\
\hline & Food and drink & 20 & 19.6 \\
\hline & $\begin{array}{l}\text { Entertainment/ } \\
\text { Recreational } \\
\text { Facilities, etc. }\end{array}$ & 26 & 25.5 \\
\hline & $\begin{array}{l}\text { Business/ } \\
\text { Meeting Client }\end{array}$ & 2 & 2.0 \\
\hline & Gambling & 16 & 15.7 \\
\hline \multirow{5}{*}{$\begin{array}{l}\text { Frequency of Travel with } \\
\text { Star Cruise Libra }\end{array}$} & First Time & 71 & 69.6 \\
\hline & 2nd Time & 14 & 13.7 \\
\hline & 3rd Time & 9 & 8.8 \\
\hline & 4th Time & 1 & 1.0 \\
\hline & More than 5 Times & 7 & 6.9 \\
\hline \multirow{8}{*}{$\begin{array}{l}\text { How do you know about } \\
\text { Star Cruise Libra? }\end{array}$} & Radio & 1 & 1.0 \\
\hline & TV Advertising & 8 & 7.8 \\
\hline & Newspapers & 8 & 7.8 \\
\hline & Internet & 44 & 43.1 \\
\hline & Friends and Families & 18 & 17.6 \\
\hline & Magazines & 6 & 5.9 \\
\hline & Travel Agency & 14 & 13.7 \\
\hline & Other & 3 & 2.9 \\
\hline
\end{tabular}


Table 1 above showed the profile of passengers, male respondents were higher than their female counterparts with a frequency of 54 for males $(52.9 \%)$ compared to 48 for females $(47.1 \%)$. Marital status frequency for single respondents was more than married respondents, 41 for singles $(40.2 \%)$ compared to 55 for married passengers $(47.1 \%)$, while those whose status was "other" had the lowest rate at $6(5.9 \%)$. For occupation, working in the private sector at $27(26.5 \%)$ while the lowest mean for occupation was "others" with $10(9.8 \%)$. Respondents with their own business were at $26(25.5 \%)$, while those working in government stood at $20(19.6 \%)$. The rest were students at $19(18.65 \%)$. About the age, the highest frequency was for respondents aged $31-40$ at $35(34.3 \%)$ and the lowest mean was below 20 years old at $8(7.8 \%)$. Respondents over 50 years old were the second lowest at $9(8.8 \%)$. The mean was $31(30.4 \%)$ for passengers below 20 years old and 19 (18.6\%) for those between the ages of 41-50. $61.8 \%$ of respondents used services at the café/lounge. For the type of Star Cruise liner travelled on, Superstar Libra at $98(96.1 \%)$, Superstar Gemini at $1(1.0 \%)$, Superstar Aquarius was $3(2.9 \%)$. The highest category for monthly income was above $\$ 2501$ at $30(29.4 \%)$ and the lowest mean was for passengers that earned both between $\$ 1001$ 1500 and $\$ 2001-2500$ at $15(14.7 \%)$. The passengers that earned below $\$ 1000$ were at $25(24.5 \%)$, while those between \$1501-2000 were at 17 (16.7\%). The general purpose for travelling on Star Cruise Libra was $45.1 \%$ loved vacationing on the sea while $54.9 \%$. $25.5 \%$ of respondents chose to travel for the entertainment or recreational facilities, $2 \%$ travelled for business or meeting clients, and $15.7 \%$ gambling. $69.6 \%$ were first-time passengers, $13.7 \%$ were second-time passengers, $8.8 \%$ were third-time passengers, $6.9 \%$ travelled aboard Star Cruise Libra more than five times and $1 \%$ were travelling for their fourth time. Respondents heard about Star Cruise from the Internet at $44(43.1 \%)$ while the lowest was for those who first heard about it via radio at $1(1.0 \%)$. The means for other sources of information were as follows: $8(7.8 \%)$ for both TV advertising and newspapers, 18 (17.6\%) for family and friends, $6(13.7 \%)$ for magazines, $14(13.7 \%)$ for travel agencies, and $3(2.9 \%)$ for "other."

Table-2. Service Quality Dimensions

\begin{tabular}{|c|c|c|c|c|c|}
\hline Item & S.D.Agree & Disagree & Neutral & Agree & S. Agree \\
\hline \multicolumn{6}{|l|}{ Tangibility } \\
\hline Visually attractive dining area & $2 / 2.0$ & $2 / 2.0$ & $33 / 32.4$ & $47 / 46.1$ & $18 / 17.6$ \\
\hline Neat, clean, and well-dressed staff & $1 / 1.0$ & $1 / 1.0$ & $30 / 29.4$ & $52 / 51.0$ & $18 / 17.6$ \\
\hline Attractive menu that reflects the restaurant's image & $1 / 1.0$ & $6 / 5.9$ & $34 / 33.3$ & $46 / 45.1$ & $15 / 14.7$ \\
\hline Clean and attractive rooms & $1 / 1.0$ & $4 / 3.9$ & $23 / 22.5$ & $51 / 50.0$ & $23 / 22.5$ \\
\hline Inviting atmosphere & $1 / 1.0$ & $1 / 1.0$ & $23 / 22.5$ & $53 / 52.0$ & $24 / 23.5$ \\
\hline \multicolumn{6}{|l|}{ Reliability } \\
\hline $\begin{array}{l}\text { Restaurant waiters or waitresses promptly visit my } \\
\text { table and take my order }\end{array}$ & $1 / 1.0$ & $4 / 3.9$ & $37 / 36.3$ & $37 / 36.3$ & $23 / 22.5$ \\
\hline Staff quickly correct anything wrong & $2 / 2.0$ & $2 / 2.0$ & $45 / 44.1$ & $37 / 36.3$ & $16 / 36.3$ \\
\hline Staff greet me in a good manner & $2 / 2.0$ & $1 / 1.0$ & $23 / 22.5$ & $54 / 52.9$ & $22 / 21.6$ \\
\hline Staff provide an accurate quest check & $2 / 2.0$ & $2 / 2.0$ & $35 / 34.3$ & $48 / 47.1$ & $15 / 14.7$ \\
\hline Staff are dependable and consistent & $1 / 1.0$ & $3 / 2.9$ & $28 / 27.5$ & $49 / 48.0$ & $21 / 20.6$ \\
\hline \multicolumn{6}{|l|}{ Responsiveness } \\
\hline $\begin{array}{l}\text { Staff work in shifts to help each other maintain } \\
\text { speed and quality of service }\end{array}$ & $2 / 2.0$ & $2 / 2.0$ & $39 / 38.2$ & $35 / 34.3$ & $24 / 23.5$ \\
\hline Staff help me within an acceptable period of time & $1 / 1.0$ & $3 / 2.9$ & $36 / 35.3$ & $50 / 49.0$ & $12 / 11.8$ \\
\hline $\begin{array}{l}\text { Customers are told exactly when services will be } \\
\text { performed }\end{array}$ & $2 / 2.0$ & $6 / 5.9$ & $37 / 36.3$ & $43 / 42.2$ & $14 / 13.7$ \\
\hline $\begin{array}{l}\text { Cruise staff make extra effort to handle my special } \\
\text { requests }\end{array}$ & $1 / 1.0$ & $7 / 6.9$ & $37 / 36.3$ & $43 / 42.2$ & $13 / 12.7$ \\
\hline Staff provide prompt and quick service & $1 / 1.0$ & $3 / 2.9$ & $29 / 28.4$ & $51 / 50.0$ & $18 / 17.6$ \\
\hline \multicolumn{6}{|l|}{ Assurance } \\
\hline $\begin{array}{l}\text { Star Cruise staff makes me feel comfortable and } \\
\text { confident in my dealing with them }\end{array}$ & $1 / 1.0$ & $4 / 3.9$ & $27 / 26.5$ & $55 / 53.9$ & $15 / 14.7$ \\
\hline $\begin{array}{l}\text { Star Cruise shows consistency and reliability in its } \\
\text { service }\end{array}$ & $2 / 2.0$ & $1 / 1.0$ & $30 / 29.4$ & $58 / 56.9$ & $11 / 10.8$ \\
\hline $\begin{array}{l}\text { Star Cruise has staff who are both able and willing } \\
\text { to give information }\end{array}$ & $1 / 1.0$ & $7 / 6.9$ & $32 / 31.4$ & $50 / 49.0$ & $12 / 11.8$ \\
\hline Staff can answer my questions fully & $1 / 1.0$ & $3 / 2.9$ & $32 / 31.4$ & $52 / 51.0$ & $14 / 13.7$ \\
\hline Star Cruise makes me feel personally safe & $1 / 1.0$ & $1 / 1.0$ & $24 / 23.5$ & $48 / 47.1$ & $28 / 27.5$ \\
\hline \multicolumn{6}{|l|}{ Empathy } \\
\hline $\begin{array}{l}\text { Staff are sensitive to my individual needs and } \\
\text { wants, rather than always relying on policies and } \\
\text { procedures }\end{array}$ & $2 / 2.0$ & $4 / 3.9$ & $37 / 36.3$ & $47 / 46.1$ & $12 / 11.8$ \\
\hline $\begin{array}{l}\text { Star Cruise has operating hours that are convenient } \\
\text { to all visitors/guests }\end{array}$ & $6 / 5.9$ & $8 / 7.8$ & $41 / 40.2$ & $32 / 31.4$ & $15 / 14.7$ \\
\hline $\begin{array}{l}\text { Star Cruise staff anticipates my individual needs } \\
\text { and wants }\end{array}$ & $3 / 2.9$ & $3 / 2.9$ & $38 / 37.3$ & $48 / 47.1$ & $10 / 9.8$ \\
\hline Star Cruise staff are polite and courteous with me & $1 / 1.0$ & $1 / 1.0$ & $31 / 30.4$ & $52 / 51.0$ & $17 / 16.7$ \\
\hline $\begin{array}{l}\text { Star Cruise seems to have the best interest of the } \\
\text { customer at heart }\end{array}$ & $1 / 1.0$ & $3 / 2.9$ & $33 / 32.4$ & $46 / 45.1$ & $19 / 18.6$ \\
\hline
\end{tabular}


Based on the table above, $46.1 \%$ agree with the attractiveness of the dining area, $32.4 \%$ were neutral, and $17.6 \%$ were strongly agree. The staff members were clean, neat and appropriately dressed with $51 \%$, and $29.4 \%$ with neutral. Star Cruise had an attractive menu that jibed with the image of the restaurant with $45.1 \%, 14.7 \%$ strongly agree, and $33.3 \%$ neutral. $50 \%$ of the respondents agreed that Star Cruise had rooms that were thoroughly clean and attractive, $22.5 \%$ neutral and strongly agree. The Star Cruise's atmosphere was inviting with 52\%, 23.5\% strongly agree, $22.5 \%$ with neutral. $36.3 \%$ of the respondents were neutral about whether the Star cruise restaurant's waiters or waitresses approached their table promptly and offered to take their order, while $22.5 \%$ were strongly agree, and $3.9 \%$ with disagree. $52.9 \%$ of the respondents agreed that star cruise staff greeted them in a good manner. $22.5 \%$ of the respondents responded with neutral, $21.6 \%$ of the respondents with strongly agree. Star cruise staff provided an accurate quest check with $47.1 \%, 34.3 \%$ of the respondents responded with neutral, $14.7 \%$ with strongly agree. $38.2 \%$ were neutral regarding whether Star Cruise, during its busy times, had staff shift around to assist one another in maintaining both the promptness and quality of service. $34.3 \%$ of the respondents agreed in this regard. $23.5 \%$ responded with strongly agree. Star Cruise staff helped them within an acceptable period with $49.0 \%, 35.3 \%$ responded with neutral; while $11.8 \%$ were strongly agree. Based on the overall analysis, respondents shows their satisfaction about the five dimensions of service quality.

Table-3. Overall Satisfaction of Star Cruise Customers

\begin{tabular}{|c|c|c|c|c|c|}
\hline Item & S.D. Agree & Disagree & Neutral & Agree & S. Agree \\
\hline $\begin{array}{l}\text { My first impression of this Star Cruise } \\
\text { was very good }\end{array}$ & $1 / 1.0$ & $1 / 1.0$ & $24 / 23.5$ & $53 / 52.0$ & $23 / 22.5$ \\
\hline $\begin{array}{l}\text { The taste of the food on Star Cruise was } \\
\text { excellent }\end{array}$ & $1 / 1.0$ & $3 / 2.9$ & $32 / 31.4$ & $56 / 54.9$ & $10 / 9.8$ \\
\hline $\begin{array}{l}\text { I was satisfied with the quality of food } \\
\text { on Star Cruise }\end{array}$ & $1 / 1.0$ & $6 / 5.9$ & $30 / 29.4$ & $53 / 52.0$ & $12 / 11.8$ \\
\hline $\begin{array}{l}\text { I was satisfied with the level of } \\
\text { teamwork and cooperation displayed by } \\
\text { staff }\end{array}$ & $1 / 1.0$ & $4 / 3.9$ & $31 / 30.4$ & $47 / 46.1$ & $19 / 18.6$ \\
\hline $\begin{array}{l}\text { The speed of service met my } \\
\text { expectations }\end{array}$ & $1 / 1.0$ & $5 / 4.9$ & $32 / 31.4$ & $45 / 44.1$ & $19 / 18.6$ \\
\hline $\begin{array}{l}\text { I was satisfied with the performance of } \\
\text { Star Cruise staff }\end{array}$ & $2 / 2.0$ & $3 / 2.9$ & $31 / 30.4$ & $49 / 48.0$ & $17 / 16.7$ \\
\hline $\begin{array}{l}\text { I was satisfied with the design and } \\
\text { ambience of Star Cruise }\end{array}$ & $1 / 1.0$ & $3 / 2.9$ & $25 / 24.5$ & $51 / 50.0$ & $22 / 21.6$ \\
\hline $\begin{array}{l}\text { I was satisfied with the safety and } \\
\text { security aboard Star Cruise }\end{array}$ & $2 / 2.0$ & $0 / 0$ & $20 / 19.6$ & $59 / 57.8$ & $21 / 20.6$ \\
\hline $\begin{array}{l}\text { Overall, I was satisfied with the service I } \\
\text { experienced on Star Cruise }\end{array}$ & $1 / 1.0$ & $4 / 3.9$ & $28 / 27.5$ & $50 / 49.0$ & $19 / 18.6$ \\
\hline $\begin{array}{l}\text { Overall, I was satisfied with the way the } \\
\text { service was delivered }\end{array}$ & $0 / 0$ & $3 / 2.9$ & $32 / 31.4$ & $49 / 48.0$ & $18 / 14.6$ \\
\hline
\end{tabular}

Table 3 shows that $52.0 \%$ of the respondents agreed that their first impression of this Star Cruise was very good. $23.5 \%$ responded with neutral, and $22.5 \%$ with strongly agree. The taste of the food on Star Cruise was excellent $54.9 \%, 31.4 \%$ responded were neutral, and $9.8 \%$ with strongly agree. $52.0 \%$ of the respondents agreed that they were satisfied with the quality of food on Star Cruise. $29.4 \%$ responded with neutral, $11.8 \%$ with strongly agree. Teamwork and coordination were displayed by the staff was satisfactory with $46.1 \%$ of the respondents agreed that $30.4 \%$ responded with neutral, $18.6 \%$ with strongly agree. Half of the respondents $44.1 \%$ agreed that the speed of service met their expectations. $31.4 \%$ responded with neutral, $18.6 \%$ with strongly agree. $48.0 \%$ of the respondents agreed that they were satisfied with the performance of the Star Cruise staff. $30.4 \%$ responded with neutral, $16.7 \%$ with strongly agree. $50.0 \%$ of the respondents agreed that they were satisfied with the design and ambience of Star Cruise, $24.5 \%$ responded with neutral; while $21.6 \%$ with strongly agree. $57.8 \%$ agreed that they felt satisfied with the safety and security aboard Star Cruise. $19.6 \%$ responded with neutral, and $20.6 \%$ with strongly agree. The respondents agreed that their overall satisfaction with the service they experienced on Star Cruise with $49.0 \%, 27.5 \%$ responded with neutral, $27.5 \%$ with strongly agree. 


\section{Descriptive Analysis}

Table-4. Service Quality Dimensions of Descriptive Analysis

\begin{tabular}{|c|c|c|c|c|c|}
\hline Item & $\mathbf{N}$ & Min & Max & Mean & Std.Deviation \\
\hline Star Cruise makes me feel personally safe. & 102 & 1.00 & 5.00 & 3.99 & .802 \\
\hline The atmosphere aboard Star Cruise is inviting. & 102 & 1.00 & 5.00 & 3.96 & .769 \\
\hline The Star Cruise staff greet me in a good manner. & 102 & 1.00 & 5.00 & 3.91 & .809 \\
\hline $\begin{array}{l}\text { Star Cruise has rooms that are thoroughly clean } \\
\text { and attractive. }\end{array}$ & 102 & 1.00 & 5.00 & 3.89 & .831 \\
\hline $\begin{array}{l}\text { Star Cruise staff make extra effort to handle my } \\
\text { special requests. }\end{array}$ & 102 & 1.00 & 33.00 & 3.88 & 3.028 \\
\hline $\begin{array}{l}\text { The Star Cruise staff are dependable and } \\
\text { consistent. }\end{array}$ & 102 & 1.00 & 5.00 & 3.84 & .817 \\
\hline 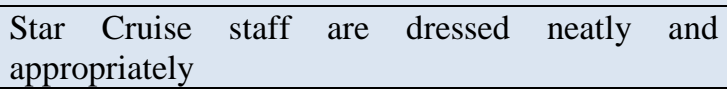 & 102 & 1.00 & 5.00 & 3.83 & .758 \\
\hline $\begin{array}{l}\text { The Star Cruise staff are polite and courteous with } \\
\text { me. }\end{array}$ & 102 & 1.00 & 5.00 & 3.81 & .754 \\
\hline $\begin{array}{l}\text { The Star Cruise staff provide prompt and quick } \\
\text { service. }\end{array}$ & 102 & 1.00 & 5.00 & 3.80 & .796 \\
\hline $\begin{array}{l}\text { Star Cruise staff make me feel comfortable and } \\
\text { confident in my dealing with them. }\end{array}$ & 102 & 1.00 & 5.00 & 3.77 & .782 \\
\hline $\begin{array}{l}\text { Star Cruise seems to have the best interests of the } \\
\text { customer at heart. }\end{array}$ & 102 & 1.00 & 5.00 & 3.77 & .819 \\
\hline $\begin{array}{l}\text { During peak hours, Star Cruise has staff shift to } \\
\text { assist one another in maintaining both the } \\
\text { promptness and quality of service. }\end{array}$ & 102 & 1.00 & 5.00 & 3.75 & .905 \\
\hline $\begin{array}{l}\text { The Star Cruise restaurant waiters or waitresses } \\
\text { promptly visit my table and take my order. }\end{array}$ & 102 & 1.00 & 5.00 & 3.75 & .883 \\
\hline Star Cruise has a visually attractive dining area. & 102 & 1.00 & 5.00 & 3.75 & .837 \\
\hline $\begin{array}{l}\text { Star Cruise shows consistency and reliability in its } \\
\text { service. }\end{array}$ & 102 & 1.00 & 5.00 & 3.73 & .743 \\
\hline $\begin{array}{l}\text { Star Cruise has staff who can answer my question } \\
\text { fully. }\end{array}$ & 102 & 1.00 & 5.00 & 3.73 & .769 \\
\hline $\begin{array}{l}\text { The Star Cruise staff provides an accurate quest } \\
\text { check. }\end{array}$ & 102 & 1.00 & 5.00 & 3.70 & .815 \\
\hline $\begin{array}{l}\text { The Star Cruise staff helps me within an } \\
\text { acceptable period of time. }\end{array}$ & 102 & 1.00 & 5.00 & 3.67 & .759 \\
\hline $\begin{array}{l}\text { The Star Cruise restaurant has an attractive menu } \\
\text { that reflects its image. }\end{array}$ & 102 & 1.00 & 5.00 & 3.66 & .836 \\
\hline $\begin{array}{l}\text { Star Cruise has staff who are both capable and } \\
\text { willing to provide me with information about } \\
\text { menu items, including their ingredients and how } \\
\text { they were prepared. }\end{array}$ & 102 & 1.00 & 5.00 & 3.63 & .817 \\
\hline $\begin{array}{l}\text { Star Cruise has staff who attend to my individual } \\
\text { needs, rather than solely relying on company } \\
\text { policies and procedures. }\end{array}$ & 102 & 1.00 & 5.00 & 3.61 & .821 \\
\hline $\begin{array}{l}\text { The Star Cruise staff quickly corrects anything } \\
\text { wrong. }\end{array}$ & 102 & 1.00 & 5.00 & 3.61 & .844 \\
\hline $\begin{array}{l}\text { Star Cruise tells customers exactly when services } \\
\text { will be performed. }\end{array}$ & 102 & 1.00 & 5.00 & 3.59 & .870 \\
\hline $\begin{array}{l}\text { The Star Cruise staff anticipates my individual } \\
\text { needs and wants. }\end{array}$ & 102 & 1.00 & 5.00 & 3.57 & .825 \\
\hline $\begin{array}{l}\text { Star Cruise has operating hours that are convenient } \\
\text { to all visitors/guests. }\end{array}$ & 102 & 1.00 & 5.00 & 3.41 & 1.027 \\
\hline
\end{tabular}

The highest mean point obtained from the service quality dimensions was 3.99 for Star Cruise making passengers feel personally safe, while the lowest mean was for the operating hours of Star Cruise at 3.41. 3.96 for respondents feeling satisfied about Star Cruise's atmosphere, 3.91 for feeling satisfied about being greeted by the staff of Star Cruise in a good manner, 3.89 for feeling satisfied about the cleanliness of passengers' rooms.

The mean 3.88 for feeling satisfied about the Star Cruise staff making extra effort to handle passengers' special requests, 3.84 for feeling satisfied about the dependability and consistency of the staff, 3.83 for feeling satisfied about how clean, neat and appropriately dressed the staff were, 3.81 for feeling satisfied with how polite and courteous the staff were, 3.80 for feeling satisfied about the promptness and speed of the Star Cruise staff's service, 3.77 for feeling comfortable and confident in dealing with the Cruise staff, 3.77 for feeling the staff had the best 
interest of the customer at heart, 3.75 for feeling satisfied with how Star Cruise during peak hours had staff shift to assist one another in maintaining both the promptness and quality of service, 3.75 for feeling satisfied with how waiters or waitresses from the Star Cruise restaurant approached respondents' tables without delay and took their orders, 3.75 for feeling satisfied with the attractiveness of the dining area, 3.73 for feeling satisfied with the consistency and reliability of service, 3.73 for feeling satisfied with the ability of Cruise staff to answer respondents' questions fully, 3.70 for feeling satisfied about passengers' being provided with an accurate quest check by Star Cruise staff,

The mean 3.67 for feeling satisfied about Star Cruise staff helping the respondents within an acceptable period of time, 3.66 for feeling satisfied about the attractiveness of the Star Cruise restaurant's menu and how it reflected its image, 3.63 for feeling satisfied about both the ability and willingness of Star Cruise staff to give respondents information about menu items, their ingredients, and methods of preparation, 3.61 for feeling satisfied about how sensitive Star Cruise staff were to passengers' individual needs and wants, rather than always relying on policies and procedures, 3.61 for feeling satisfied about how quickly Star Cruise staff corrected anything wrong, 3.59 for feeling satisfied about being told by Star Cruise staff exactly when services would be performed, 3.57 for feeling satisfied about Star Cruise staff's anticipation of the individual needs and wants of the customer, and 3.41 for feeling satisfied about the convenience of the operating hours of Star Cruise to all visitors/guests.

Table-5. Customers' Overall Satisfaction with Star Cruise

\begin{tabular}{l|l|l|l|l|l|l}
\hline Item & $\mathbf{N}$ & $\mathbf{M i n}$ & $\mathbf{M a x}$ & $\mathbf{M e a n}$ & Std. Deviation \\
\hline I was satisfied with the safety and security on Star Cruise & 102 & 1.00 & 5.00 & 3.95 & .762 \\
\hline My first impression of this Star Cruise was very good. & 102 & 1.00 & 5.00 & 3.94 & .768 \\
\hline $\begin{array}{l}\text { I was satisfied with the design and ambience of Star } \\
\text { Cruise. }\end{array}$ & 102 & 1.00 & 5.00 & 3.88 & .811 \\
\hline $\begin{array}{l}\text { In general, I was satisfied with the level of service I } \\
\text { received on Star Cruise. }\end{array}$ & 102 & 1.00 & 5.00 & 3.80 & .821 \\
\hline $\begin{array}{l}\text { In general, I was satisfied with the delivery of this } \\
\text { service. }\end{array}$ & 102 & 2.00 & 5.00 & 3.80 & .758 \\
\hline $\begin{array}{l}\text { In general, I was satisfied with the level of teamwork and } \\
\text { cooperation displayed by staff. }\end{array}$ & 102 & 1.00 & 5.00 & 3.77 & .831 \\
\hline $\begin{array}{l}\text { In general, I was satisfied with the performance and } \\
\text { professionality of Star Cruise staff. }\end{array}$ & 102 & 1.00 & 5.00 & 3.74 & .840 \\
\hline $\begin{array}{l}\text { The speed of service met my expectations. } \\
\text { The taste of the food on Star Cruise was excellent. }\end{array} 102$ & 102 & 1.00 & 5.00 & 3.74 & .852 \\
\hline I was satisfied with the quality of food on Star Cruise. & 102 & 1.00 & 5.00 & 3.67 & .798 \\
\hline
\end{tabular}

The highest mean point for passengers' satisfaction was 3.95 for security and safety aboard, while the lowest mean was 3.676 for their satisfaction regarding the quality of food on Star Cruise. The mean for the first impression of passengers of Star Cruise being very good was 3.94 and the mean for passenger satisfaction with the design and ambience of the cruise was 3.88. The mean for both overall satisfaction with the service experienced on Star Cruise and the way service was delivered was 3.803 .

\section{Conclusions}

This study focused on the relationship between the SuperStar Libra's customer satisfaction and service quality dimensions using an adapted version of the SERVQUAL scale model. Understanding how customer emotions and satisfaction work is key to retaining customers and making business sustainable. The greatest challenge for the cruise industry in the future will be coming up with viable ways to keep previous and existing customers engaged. This cannot be accomplished simply by launching marketing campaigns to boost sales for a certain period. Identifying the intricate factors that contribute to customer satisfaction must be part of long-term strategic thinking around incentivizing repeat purchases. It is hoped the findings presented here will empower cruise managers with the valueadded knowledge to remain competitive in the ever-expanding and -differentiating tourism industry.

\section{References}

Ahmed, Z. U., Johnson, J. P., Pei Ling, C., Wai Fang, T. and Kah Hui, A. (2002). Country-of-origin and brand effects on consumers' evaluations of cruise lines. International Marketing Review, 19(3): 279-302.

Albattat, A., Alsardia, K., Al-Laymoun, M., Alyaa Atikah, A. J. and Razali, I. (2019). Budget hotels' online guest reviews regarding customer satisfaction. The Journal of Social Sciences Research (TJSSR), 5(2): 522-34. Available: https://doi.org/10.32861/jssr.52.522.534

Atilgan, E., Akinci, S. and Aksoy, S. (2003). Mapping service quality in the tourism industry. Managing Service Quality An International Journal, 13(5): 412-22.

Barsky, J. D. and Labagh, R. (1992). A strategy for customer satisfaction. The Cornell Hotel and Restaurant Administration Quarterly, 35(3): 32-40.

Bitner, M. J. and Hubbert, A. R. (1994). Encounter satisfaction versus overall satisfaction versus quality. Service quality: New directions in theory and practice, 34: 72-94. 
Bloemer, J., De Ruyter, K. and Peeters, P. (1998). Investigating drivers of bank loyalty: the complex relationship between image, service quality and satisfaction. International Journal of Bank Marketing, 16(7): 276-86.

Cadotte, E. R. and Turgeon, N. (1988). Key factors in guest satisfaction. Cornell Hotel and Restaurant Administration Quarterly, 28(4): 44-51.

Caruana, A. (2002). Service loyalty. European Journal of Marketing, 36(7/8): 811-28.

Coggins Jr, A. O. (2014). The globalization of the cruise industry, A tale of ships. Worldwide Hospitality and Tourism Themes, 6(2): 138-51.

Dowling, R. K. (2006). The cruising industry. Cruise ship tourism. 3-17.

Eraqi, M. I. (2006). Tourism services quality (TourServQual) in Egypt: The viewpoints of external and internal customers. Benchmarking An International Journal, 13(4): 469-92.

Forgas-Coll, S., Palau-Saumell, R., Sánchez-García, J. and María Caplliure-Giner, E. (2014). The role of trust in cruise passenger behavioral intentions. Management Decision, 52(8): 1346-67.

GentingBerhad (2015). Group profile. Available: http://www.genting.com/groupprofile/index.htm

González, M. E. A., Comesaña, L. R. and Brea, J. A. F. (2007). Assessing tourist behavioral intentions through perceived service quality and customer satisfaction. Journal of Business research, 60(2): 153-60.

Heung, V. C. and Lam, T. (2003). Customer complaint behaviour towards hotel restaurant services. International Journal of Contemporary Hospitality Management, 15(5): 283-89.

Hsu, C. L. and Lin, J. C. C. (2016). Effect of perceived value and social influences on mobile app stickiness and inapp purchase intention. Technological Forecasting and Social Change, 108: 42-53. Available: https://www.sciencedirect.com/science/article/pii/S0040162516300348

Kjell, T. T. H. (2013). Niche marketing research: status and challenges. Marketing Intelligence \& Planning, 31(3): 272-85.

Kozak, M. and Rimmington, M. (1999). Measuring tourist destination competitiveness: conceptual considerations and empirical findings. International Journal of Hospitality Management, 18(3): 273-83.

Kwortnik, R. J. (2006). Carnival cruise lines burnishing the brand. Cornell Hotel and Restaurant Administration Quarterly, 47(3): 286-300.

Kwortnik, R. J. (2008). Shipscape influence on the leisure cruise experience. International Journal of Culture, Tourism and Hospitality Research, 2(4): 289-311.

Kwortnik, R. J. and Han, X. (2011). The influence of guest perceptions of service fairness on lodging loyalty in China. Cornell Hospitality Quarterly, 52(3): 321-32.

Liljander, V. and Strandvik, T. (1993). Estimating zones of tolerance in perceived service quality and perceived service value. International Journal of Service Industry Management, 4(2): 6-28.

Malhotra, N. and Mukherjee, A. (2004). The relative influence of organisational commitment and job satisfaction on service quality of customer-contact employees in banking call centres. Journal of Services Marketing, 18(3): 162-74.

Martinez-Garcia, E. and Raya, J. M. (2008). Length of stay for low-cost tourism. Tourism Management, 29(6): 106475.

Mason, D. D., Tideswell, C. and Roberts, E. (2006). Guest perceptions of hotel loyalty. Journal of Hospitality \& Tourism Research, 30(2): 191-206.

Mittal, V. and Kamakura, W. A. (2001). Satisfaction, repurchase intent, and repurchase behavior: Investigating the moderating effect of customer characteristics. Journal of Marketing Research, 38(1): 131-42.

Naumann, E. and Giel, K. (1995). Customer satisfaction measurement and management, Using the voice of the customer. Van Nostrand Reinhold.

Ndubisi, N. O. and Nataraajan, R. (2018). Customer satisfaction, Confucian dynamism, and long-term oriented marketing relationship: A threefold empirical analysis. Psychology \& Marketing, 35(6): 477-87.

Ostrowski, P. L., O'Brien, T. V. and Gordon, G. L. (1994). Determinants of service quality in the commercial airline industry, Differences between business and leisure travelers. Journal of Travel \& Tourism Marketing, 3(1): $19-48$.

Parasuraman, A., Zeithaml, V. A. and Berry, L. L. (1985). A conceptual model of service quality and its implications for future research. Journal of Marketing, 49(4): 41-50.

Parasuraman, A., Zeithaml, V. A. and Berry, L. L. (1988). Servqual: A multiple-item scale for measuring consumer perc. Journal of Retailing, 64(1): 12.

Parasuraman, A., Berry, L. L. and Zeithaml, V. A. (1991). Understanding customer expectations of service. Sloan Management Review, 32(3): 39-48.

Parasuraman, A., Zeithaml, V. A. and Berry, L. L. (1994). Reassessment of expectations as a comparison standard in measuring service quality: implications for further research. Journal of Marketing, 58(1): 111-24.

Pizam, A. and Ellis, T. (1999). Customer satisfaction and its measurement in hospitality enterprises. International Journal of Contemporary Hospitality Management, 11(7): 326-39.

Poon, W. C. and Lock-Teng Low, K. (2005). Are travellers satisfied with Malaysian hotels? International Journal of Contemporary Hospitality Management, 17(3): 217-27.

Sashi, C. M. (2012). Customer engagement, buyer-seller relationships, and social media. Management Decision, 50(2): 253-72.

Shen, Y., Kwan, M. P. and Chai, Y. (2013). Investigating commuting flexibility with GPS data and 3D geovisualization: a case study of Beijing, China. Journal of Transport Geography, 32: 1-11. Available: https://www.sciencedirect.com/science/article/abs/pii/S096669231300135X 
Smith (1994). The tourism product. Annals of Tourism Research, 21(3): 582-95.

Smith, Ferrari, S. and Puczkó, L. (2016). Service innovations and experience creation in spas, wellness and medical tourism. In the handbook of managing and marketing tourism experiences. Emerald Group Publishing Limited. 299-319.

Storbacka, K., Strandvik, T. and Grönroos, C. (1994). Managing customer relationships for profit: the dynamics of relationship quality. International Journal of Service Industry Management, 5(5): 21-38.

Sureshchandar, G. S., Rajendran, C. and Anantharaman, R. N. (2002). The relationship between service quality and customer satisfaction-a factor specific approach. Journal of Services Marketing, 16(4): 363-79.

Testa, M. R. and Sullivan, K. (2002). Customer satisfaction, quality in cruise industry. Hospitality Review, $20(2): 1$.

Tsiotsou, R. (2006). The role of perceived product quality and overall satisfaction on purchase intentions. International Journal of Consumer Studies, 30(2): 207-17.

Vavra, T. G. (1997). Improving your measurement of customer satisfaction: A guide to creating, Conducting, analyzing, and reporting customer satisfaction measurement programs. ASQ quality press.

Wilson, A., Zeithaml, V. A., Bitner, M. J. and Gremler, D. D. (2012). Services marketing: Integrating customer focus across the firm. 2nd ednMcGraw Hill.

Zeithaml, V. A., Berry, L. L. and Parasuraman, A. (1996). The behavioral consequences of service quality. Journal of Marketing, 60(2): 31-46. 